\title{
Efektivitas Penilaian Pembelajaran Menggunakan Google Form pada Pembelajaran Daring
}

\author{
${ }^{1}$ Rahmah Zaqiyatul Munawaroh, ${ }^{2}$ Andi Prastowo, ${ }^{3}$ Maya Nurjanah \\ Universitas Islam Negeri Sunan Kalijaga \\ Email Korespondensi:20204082011@student.uin-suka.ac.id
}

\begin{tabular}{l}
\hline \hline Article Info \\
Article history: \\
Article Accepted: 28 June 2021 \\
Publication : 11 July 2021 \\
\end{tabular}

Keywords:

assessment, learning, Google form.

\begin{tabular}{l}
\hline Article Info \\
Article history: \\
Article Accepted: 28 Juni 2021 \\
Publication : 11 Juli 2021
\end{tabular}

Keywords:

Penilaian, Pembelajaran,

Google Form

\begin{abstract}
Learning in the network implemented in pandemic covid-19 is a new challenge for the Indonesian learning system. The demands of more creativity are left to the educators for effective learning. So, too, with new options/ideas associated with the learning system, especially with the student learning assessment system. The feature of the Google form on the Google application becomes one of the options that can be used to facilitate the student learning assessment process. The study is conducted to learn the effectiveness of learning assessments using Google form on students, the strengths and deficiencies of Google form, and the knowledge of barriers students experience when using Google form. Research is conducted with a descriptive qualitative method with the data-collection of interviews and questionnaires. The results of the study say that the use of the learning assessment using Google form is considered to be effective because it makes it easier for teachers and students, both in filling out problems and process processes by teachers. Google form has an advantage such as providing an automated data-processing system, so teachers don't have to manually calculate. The barriers are affected by network activity, and the
\end{abstract} lack of understanding of students or guardians of technology.

Abstrak
Pembelajaran dalam jaringan yang diterapkan di masa pandemic covid-
19 menjadi tantangan baru bagi sistem pembelajaran di Indonesia. Tuntutan
kreativitas lebih, diserahkan kepada pendidik agar pembelajaran tetap efektif.
Begitu pun dengan adanya berbagai opsi/gagasan baru terkait sistem
pembelajaran, khususnya pada sistem penilaian pembelajaran siswa. Fitur
google form pada aplikasi google menjadi salah satu opsi yang dapat digunakan
untuk mempermudah proses penilaian pembelajaran siswa. Penelitian ini
dilakukan untuk mengetahui efektivitas penilaian pembelajaran menggunakan
google form pada siswa, kelebihan dan kekurangan penggunaan google form,
serta mengetahui hambatan yang dialami siswa ketika menggunakan google
form. Penelitian dilakukan dengan metode kualitatif deskriptif dengan teknik
pengumpulan data berupa wawancara dan kuesioner. Hasil dari penelitian
mengatakan bahwa penggunaan penilaian pembelajaran menggunakan google
form dianggap efektif karena mempermudah guru dan siswa, baik dalam
pengisian soal maupun proses olah data oleh guru. Google form memiliki
keunggulan seperti menyediakan sistem olah data secara otomatis, sehingga
guru tidak perlu menghitung secara manual. Hambatan yang terjadi dipengaruhi
oleh adanya ganguan jaringan/sinyal, serta kurangnya memahaman siswa atau
wali murid terhadap teknologi.

Corresponding Author:

Rahmah Zaqiyatul Munawaroh

Universitas Islam Negeri Sunan Kalijaga

Email: 20204082011@student.uin-suka.ac.id 


\section{PENDAHULUAN}

Pandemi Covid-19 yang berlangsung dari awal tahun 2020 berdampak pada setiap aspek di Indonesia, termasuk aspek pendidikan. kebijakan pemerintah Indonesia pada pertengahan bulan Maret 2020 melalui Kementerian Pendidikan dan Kebudayaan dan Kementerian Agama RI. menerapkan kebijakan work from home atau belajar dan bekerja dari rumah (Jamaluddin, Ratnasih, Gunawan, \& Paujiah, 2020). Tuntutan pemerintah di masa pandemi terkait proses pembelajaran menjadi sebuah polemik baru di dalam sistem pembelajaran di Indonesia. Tidak dapat dipungkiri bahwa guru harus menyesuaikan metode pengajarannya dengan kebutuhan siswa saat ini, khususnya di masa pandemi, maka perlu adanya perubahan sistem pendidikan yang bertujuan untuk mengakomodasi kebutuhan siswa (Suryanovika, 2020)

Istilah pembelajaran daring (dalam jaringan) menjadi tidak asing didengar saat ini, pembelajaran daring dilakukan untuk memenuhi kebutuhan belajar siswa selama Pandemi. Namun dipungkiri juga menimbulkan hambatan dalam belajar. Munculnya hambatan-hambatan baru terkait pembelajaran menjadi permasalahan yang harus ditelaah secara mendalam. Menurut Suryani, hambatan dalam proses pembelajaran dapat mengakibatkan turunnya minat belajar siswa (Jamaluddin et al., 2020). Salah satu hambatan yang terjadi yaitu terbatasnya kemampuan guru dalam bidang teknologi informasi dan komunikasi. Menurut Niarsa (D. S. Batubara, 2017) peraturan Menteri Pendidikan Nasional Nomor 16 Tahun 2007, kompetensi TIK bagi guru sekurang-kurangnya mempunyai dua fungsi, yaitu TIK sebagai pengembangan diri dan TIK sebagai penunjang proses pembelajaran.

Salah satu tujuan dari berkembangnya teknologi adalah untuk mempermudah pelaksanaan pendidikan (Lestari \& Putra, 2020). Berkembangnya teknologi dan komukasi dalam bidang pendidikan memberikan banyak opsional yang dapat digunakan. Baik itu yang bertujuan untuk mempermudah proses pembelajaran dalam bentuk metode, media pembelajaran, serta sistem penilaian pembelajaran. Surya mengatakan (Lestari \& Putra, 2020) program pembelajaran yang efektif ditandai dengan adanya ciri-ciri berikut: 1) tersampaikannya tujuan instruksional yang telah ditetapkan kepada siswa, 2) memberikan pengalaman belajar secara atraktif, dengan melibatkan siswa secara aktif sehingga menunjang siswa untuk mencapai tujuan instruksional, 3) memiliki sarana penunjang dalam proses belajar mengajar.

Berkembangnya teknologi dan komunikasi tidak hanya membantu proses pembelajaran tetapi juga dalam hal evaluasi pembelajaran, baik itu evaluasi yang bersifat latihan-latihan soal atau evaluasi resmi seperti ujian sekolah. (Imania \& Bariah, 2019).

Menurut Jabbarifat, evaluasi pembelajaran ditujukan kepada siswa agar siswa mampu menunjukkan apa yang sudah mereka pelajari, atau bahkan yang belum mereka pelajari (Suryanovika, 2020). Pentingnya penilaian dalam pembelajaran yaitu sebagai alat pemerolehan data yang bertujuan untuk meningkatkan kualitas pembelajaran (H. H. Batubara, 2016). Di era teknologi ini, alternatif teknik evaluasi pembelajaran akan sangat membantu dikarenakan lebih ramah lingkungan, hemat waktu, dan praktis.

Pembelajaran berbasis teknologi terbagi menjadi dua, ada yang disebut dengan pembelajaran berbasis komputer, dan pembelajaran berbasis web (e-learning). Pembelajaran berbasis web dibangun dengan beberapa prinsip yang berperan menentukan keberhasilan pembelajaran di tahap implementasi. Efektifitas pembelajaran berbasis web pada dasarnya bergantung pada pemegang kepentingan. Maka sulit menentukan prinsip utama, namun setidaknya dalam pembelajaran berbasis web harus terdapat: 1) Interaksi, 2) Ketergunaan, 3) dan Relevansi. (Rusman, 2028)

E-learning dapat diakses tanpa mengenal tempat dan waktu selama peserta didik memiliki jaringan internet (Rahmanto \& Bunyamin, 2020). Terdapat beberapa karakteristik yang ada pada E-Learning, 1) Interactivity (interaktivitas), yaitu menyediakan jalur komunikasi yang lebih banyak baik secara langsung (synchronous) maupun tidak langsung. (asynchronous). 2) Independency ( kemandirian), yaitu fleksibeldalam segi waktu, tempat, pengajar, dan bahan ajar (pembelajaran yang terpusat pada siswa). 3) Accessibility (aksesibilitas), yaitu akses untuk bahan atau sumber belajar menjadi mudah untuk diperoleh. 4) Enrichment (pengayaan), yaitu 
kemungkinan penggunaan perangkat teknologi seperti video streaming, simulasi dan animasi menjadi sebuah kegiatan atau bahkan pengayaan dalam pembelajaran. (Rusman, 2028)

Formulir Google atau kita sebut google form merupakan salah satu fitur berbasis elearning yang dapat berguna untuk guru atau siswa. Pada Google Formulir terdapat sistem hitung otomatis sebagai umpan balik kepada siswa sehingga guru tidak perlu menghitung secara manual hasil penilaian belajar siswa. Google form juga dapat digunakan untuk survey dan sejenisnya, dan dapat dimanfaatkan sebagai ujian online (Lestari \& Putra, 2020). Selain itu, google form juga memiliki beberapa keunggulan lain, diantaranya: (1) formulir yang bersifat responsive, (2) memiliki tampilan yang menarik, (3) ada berbagai jenis tes yang dapat digunakan, (4) Responden dapat memberikan feedback dengan cepat di mana pun, (5) hasil yang diperoleh langsung dianalisis dan tersusun secara otomatis, (6) dapat dikerjakan bersama orang lain (H. H. Batubara, 2016). bentuk Google form juga berbeda dengan alat survey online lainnya, banyak fitur dari formulir Google yang tidak tersedia dalam alat survey online lainnya

Menurut Mutadi (2018) dalam Kartono (2020) google form menyediakan beberapa fitur atau fasilitas, seperti mendesain formulir online untuk kuis/ulangan harian dengan bentuk pertanyaan yang variatif, google form dapat dimodifikasi dengan menggunakan template, mempermudah membagikan google form yang telah dibuat kepada siswa dengan menggunakan link website, dan menempelkan form tes/ujian online yang telah dibuat dalam blog atau website.

Sianipar, A.Z. memaparkan bahwa Google Form memiliki banyak fungsi di dalam dunia pendidikan, diantaranya: a) Mengumpulkan pendapat pada laman website, b) Mengumpulkan bermacam data dosen/mahasiswa/guru/siswa pada halaman website, c) Menciptakant formulir pendaftaran berbasis online pada sekolah, d) Memberikan tugas latihan/ulangan secara online menggunakan laman website, e) Memberikan kuesioner terhadap orang-orang. (Lestari \& Putra, 2020)

Namun yang perlu digaris bahwahi adalah, sehebat apapun web/e-learning dalam membantu proses belajar, yang menjadi focus utama tetaplah diri pelajar sendiri (Rusman, 2018). Begitupun web hanya berperan sebagai sarana atau alat bantu yag bertujuan untuk memudahkan proses pembelajaran. Bahkan sering kali terdapat hambatan dalam penggunaannya, terutama dalam pembelajaran daring, terbatasnya kuota, banyaknya tugas, penguasaan IT yang masih terbatas, jaringan ang tidak stabil, telat 'masuk' kuliah karena tidak terbiasa menggunakan daring, jaringan yang tidak stabil karena kondisi responden yang ada di pedesaan, dan lain sebagainya (Jamaluddin et al., 2020).

Ada beberapa prinsip yang mendasari penilaian proses dan hasil, yaitu: valid, objektif, adil, terpadu, menyeluruh, sistematis, beracuan kriteria, dan akuntabel (Farida, 2017). Maka tujuan dari penelitian ini adalah untuk mengetahui efektivitas proses penilaian pembelajaran menggunakan google form, serta keuntungan hambatan dan yang didapat saat menggunakan google form.

Penelitian mengenai pencarian efektivitas penggunaan google form sebelumnya pernah dilakukan dalam beberapa penelitian, diantaranya oleh Lestari \& Putra (2020). Penelitian ini dilakukan dengan metode deskriptif dengan pendekatan kualitatif. Teknik pengumpulan data menggunakan tes dan angket. Yang menjadi subyek penelitian ini adalah siswa kelas VII di SMPN 1 Tajinan Malan. Hasil penelitian menunjukkan hasil belajar siswa yang tuntas mencapai 75.4\% dan berada pada klasifikasi baik; respon siswa terhadap pemberian tugas Google Form berada pada kategori baik. penelitian yang dilakukan Lestari \& Putra (2020) berbeda dengan penelitian yang dilakukan peneliti saat ini, peneliti menggunakan teknik pengumpulkan data berupa angket dan wawancara, serta subjek yang digunakan yaitu ditujukan pada siswa di jenjang sekolah dasar.

Begitu pula dengan penelitian yang dilakukan oleh Thohir dan Muslimah (2020). Penelitiannya bertujuan untuk mengetahui dan menjelaskan tata cara penggunaan evaluasi hasil belajar siswa dengan google form. Metode yang digunakan adalah kualitatif deskriptif dengan teknik pengumpulan data berupa kuesioner dan wawancara. Subjek penelitian ditujukan pada siswa kelas X SMA Muhammadiyah 4 Surabaya. Hasil penelitian menunjukkan bahwa 
persyaratan dalam menggunakan Google Form hanya memiliki gadget, akun google dan kuota internet. Pada menu depan form google terdapat dua bagian yaitu Question dan Responses. Beralih dari tab Pertanyaan ke tab Tanggapan di editor formulir Anda untuk melihat tanggapan saat ini ke formulir Anda dan tautkan ke spreadsheet. Kemudian klik pada tiga titik di samping "+" lalu pilih tanggapan unduhan. Dari spreadsheet tersebut dapat diperoleh informasi lengkap tentang timestamp, alamat email, nama, kelas, skor, dan jawaban soal siswa secara tertib dan otomatis. Penelitian diatas berbeda dengan penelitian saat ini kerena membahas mengenai tatacara penggunaan dari google form, sedangkan penelitian saat ini bertujuan untuk mengetahui efektivitas penggunaan google form dalam proses penilaian hasil belajar siswa pada pembelajaran daring di masa pendemi covid-19.

Uraian latar belakang diatas memotivasi peneliti untuk melakukan penelitian yang berhubungan dengan penggunaan google form dalam penilaian pembelajaran. Adapun penelitian yang akan dilakukan akan mengambil judul Efektivitas Penilaian Pembelajaran Menggunakan Google Form pada Pembelajaran Daring di SD/MI. Penggunaan Media Pembelajaran Berbasis Teknologi.

\section{METODE PENELITIAN}

Penelitian ini merupakan penelitian kualitatif deskriptif. Menurut Sugiyono, metode deskriptif kualitatif adalah menganalisis data dengan mendeskripsikan data yang telah dikumpulkan apa adanya tanpa bermaksud membuat kesimpulan yang dapat diterapkan untuk umum atau generalisasi (Thohir \& Muslimah, 2020). Teknik pengumpulan data yang digunakan berupa kuesioner dan wawancara. Menurut Sugiono, kuesioner merupakan teknik pengumpulan data yang dilakukan dengan cara memberi seperangkat pertanyaan atau pernyataan tertulis kepada responden untuk dijawab. Jenis kuesioner yang digunakan adalah kuesioner tertutup atau terstruktur. Sedangkan wawancara digunakan untuk mengetahui hal-hal lebih mendalam dari responden dengan jumlah responden yang sedikit (Sugiyono, 2018).

Penelitian dilaksanakan pada 22-24 Maret 2021 dengan responden yang berjumlah 49 orang siswa MI Miftahul Falah Bandung, MI Al-Musthofa Bandung, dan SD Tunas Harapan Ar-Raudhah. Data diperoleh melalui pengisian pertanyaan-pertanyaan yang dibagikan kepada seluruh responden dalam bentuk google form. Selanjutnya data yang terkumpul dianalisis untuk dideskripsikan.

Adapun teknik wawancara akan diberikan kepada guru yang dikatakan memenuhi kriteria tertentu untuk melengkapi sumber data penelitian. Pertanyaan yang diberikan mengacu pada prinsip atau karakteristik penilaian pembelajaran yang telah ditentukan, adapun beberapa pertanyaan yang akan diberikan kepada siswa dalam bentuk angket melalui google form, diantaranya seperti: (1) Apakah adik-adik pernah menggunakan google form?, (2) Alat kamukasi apa yang digunakan ketika mengerjakan soal dengan google form?, (3) Alat komunikasi milik siapa yang digunakan ketika ulangan?, (4) Apakah adik-adik senang dengan mengerjakan soal menggunakan google form?, (5) Dengan siapa adik-adik mengerjakan soal ulangan menggunakan google form?, (6) Berapa lama waktu yang digunakan ketika mengerjakan soal dengan google form?, (7) Ulangan akan lebih mudah jika menggunakan?, (8) Apa kendala ketika mengerjakan soal dengan google form?.Alur penelitian sebaiknya disajikan di bagian ini dilengkapi dengan keterangan gambar. Keterangan gambar diletakkan menjadi bagian dari judul gambar (figure caption) bukan menjadi bagian dari gambar. Metode-metode yang digunakan dalam penyelesaian pengabdian dituliskan di bagian ini.

\section{HASIL DAN PEMBAHASAN (12pt)}

Hasil pengumpulan data menggunakan kuesioner yang ditujukan kepada siswa dan wawancara kepada guru dapat dipaparkan sebagai berikut;

Dari 49 responden, dapat dilihat bahwa responden memberikan respon yang variatif. Keterangan lebih rinci diperoleh data seperti berikut: 


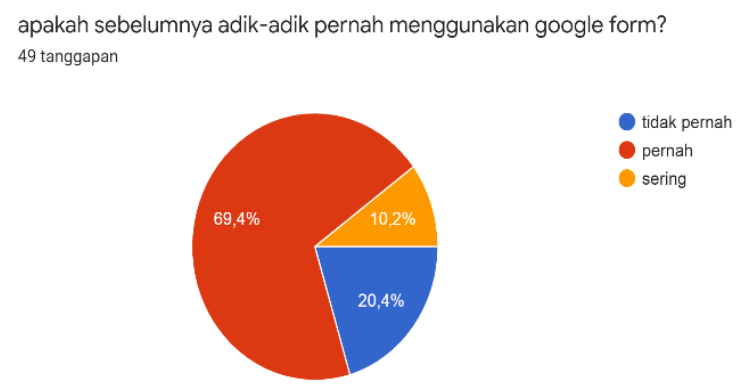

\begin{abstract}
gambar 1
Mengenai pertanyaan nomer 1 yaitu :"apakah sebelumnya adik-adik pernah menggunakan google form?" dijawab oleh responden cukup variatif. Respon yang diterima berupa "tidak pernah" sebanyak 20,4\%, "pernah" sebanyak 69,4\%, dan "sering" sebanyak $10,2 \%$. Hal ini menunjukkan bahwa sebagian besar responden atau siswa sudah pernah atau bahkan sering menggunakan fitur google form dalam proses pembelajaran.
\end{abstract}

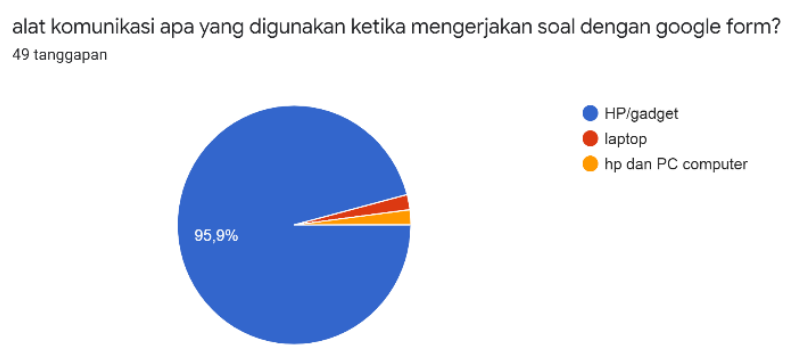

gambar 2 alat komunikasi

Tanggapan mengenai pertanyaan nomer 2 yaitu: "alat komunikasi apa yang digunakan ketika mengerjakan soal dengan google form?" mendapat persentase jawaban dari responden dengen cukup dominan ke satu pilihan. 95,9\% menjawab "hp/gadget", sebanyak $2 \%$ menjawab laptop, dan $2 \%$ menjawab hp dan pc komputer. Maka dapat kita ketahui bahwa alat yang paling banyak digunakan oleh siswa untuk mengakses google form adalah hp/gadget, dan hanya ada sebagian siswa yang menggunakan alat elektronik lain seperti laptop dan Pc computer.

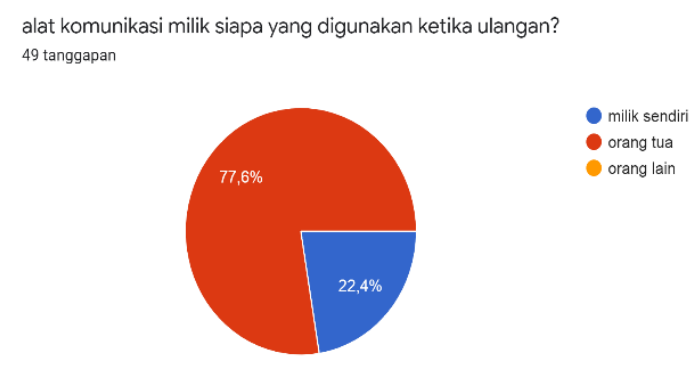

gambar 3 kepemilikan alat komunikasi

Tanggapan reponden terkait pertanyaan nomer dua yaitu: "alat komunikasi milik siapa yang digunakan setika ulangan?" mendapat respon yang cukup mendominasi ke satu pilihan juga, jawaban "milik sendiri" mendapat persentase sebanyak 22,4\%, "orang tua" sebanyak $77,6 \%$, dan "orang lain" sebanyak 0\%. Dari tanggapan tersebut menunjukkan bahwa lebih banyak siswa yang menggunakan alat komunikasi milik orangtuanya dibanding menggunakan milik sendiri atau orang lain. Hal ini menunjukkan bahwa siswa sudah terfasilitasi oleh orang tua untuk bisa mengikuti pembelajaran dengan baik. 


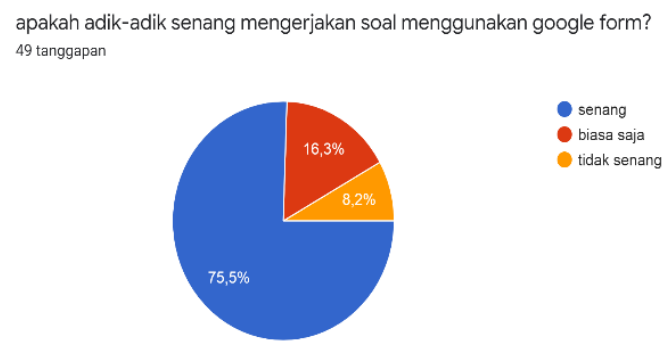

gambar 4 minat/ketertarikan siswa

Pada bagian ini, responden mendapat pertanyaan nomer empat yang berbunyi: "apakah adik-adik senang mengerjakan soal menggunakan google form?". Persentase jawaban dari pertanyaan tersebut yaitu $75,5 \%$ responden menjawab "senang", $16,3 \%$ responden menjawab "biasa saja", dan 8,3\% responden menjawab "tidak senang". Maka dapat kita ketahui bahwa minat siswa dalam mengerjakan soal menggunakan google form mendominasi jawaban yang lain. Pelatihan pembelajaran bagi siswa melalui google form membuat siswa merasa senang sehingga akan meningkatkan minat dan semangat siswa dalam pembelajaran. Seperti yang dikatakan Nurhidayah (Wijayanti \& Hermanto, 2021) bahwa semakin tinggi minat belajar dan dukungan belajar dari pihak orang tua, maka semakin tinggi pula motivasi belajar mahasiswa dalam mengikuti pembelajaran. Namun, perlu juga adanya analisis lebih mendalam terkait alasan siswa merasa tidak senang menggunakan google form.

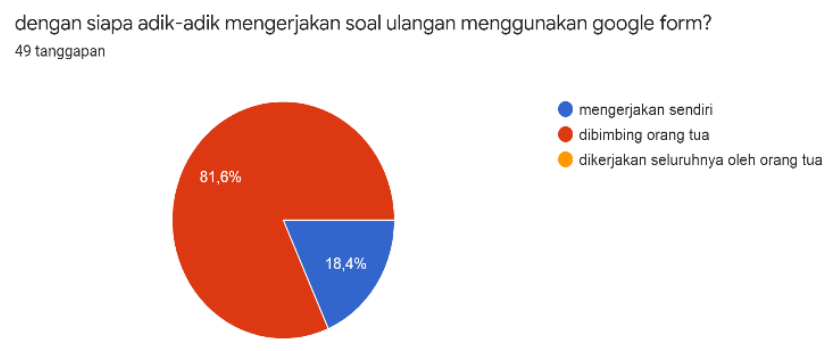

gambar 5 kemandirian

Tanggapan responden mengenai pertanyaan nomer tiga yaitu: "dengan siapa adik-adik mengerjakan soal ulangan menggunakan google form?". Mendapat respon berupa, 81,6\% siswa menjawab "dibimbing oleh orang tua", menjawab "mengerjakan sendiri, dan menjawab " dikerjakan seluruhnya oleh orang tua". Maka tanggapan dari responden menunjukkan bahwa lebih banyal siswa yang masih harus dibimbing oleh orangtuanya dalam mengerjakan soal melalui google form dibandingkan dengan mengerjakan dengan mandiri/sendiri. Namun hal ini juga menandakan bahwa tdiak ada siswa yang tidak mau mengerjakan soal sehingga harus dikerjakan oleh orang taunya. Siswa sudah meu dalam mengerjakan soal, hanya saja masih perlu dibimbing oleh orang tua/wali.

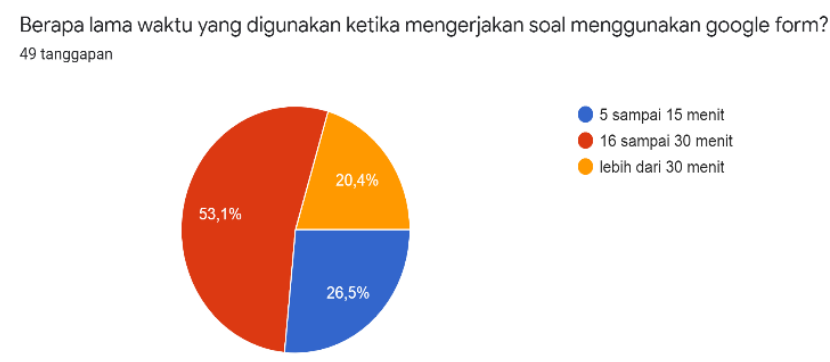

gambar 6 estimasi waktu

Pada gambar ini, terdapat pertanyaan nomer lima yaitu: "berapa lama waktu yang digunakan ketika mengerjakan soal menggunakan google form?. Maka jawaban dari responden yaitu: jawaban "5 sampai 15 menit" memiliki persentase sebesar 26,5\%, jawaban "16 sampai 30 
menit" memiliki persentase sebesar 53,1\%, dan jawaban lebih dari 30 menit" memiliki persentase sebesar 20,4\%. Maka dapat kita ketahui bahwa siswa dominan memiliki tingkat kecepatan yang baik dalam mengerjakan soal, namun tidak sedikit pula yang menyelesaikan soal dengan waktu yang masih terbilang lambat.

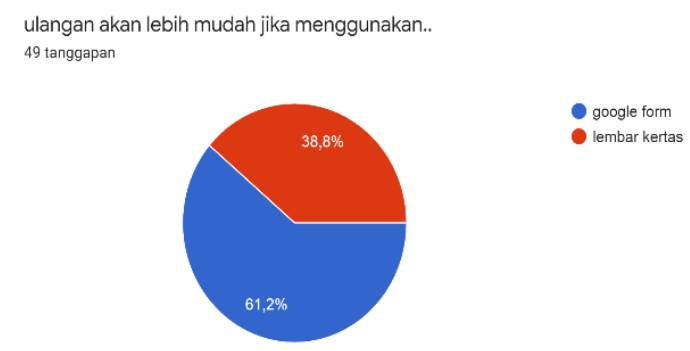

gambar 7

Pada gambar ini, responden mendapat pertanyaan yaitu: "ulangan akan lebih ,mudah jika menggunakan?". Maka responden yang memberi jawaban "google form" sebanyak $61,2 \%$, dan jawaban "kertas lembar" sebanyak 38,8\%. Maka dapat kita ketahui bahwa lebih banyak siswa yang menganggap bahwa pengerjakan soal ulangan menggunakan google form lebih mudah dari pada menggunakan lembar kertas.

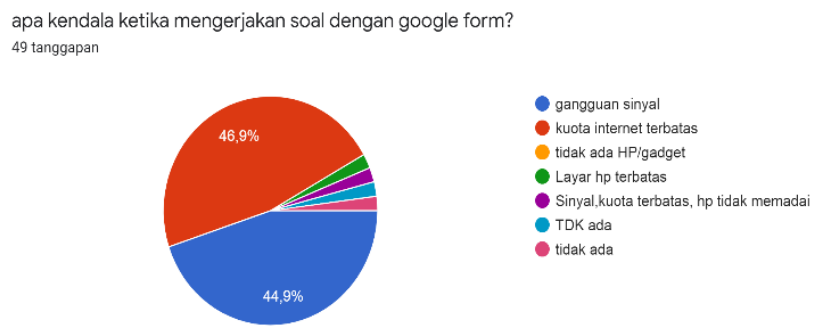

\section{gambar 8 hambatan}

Pada bagian ini, responden mendapat pertanyaan yaitu: "apa kendala ketika mengerjakan soal dengan google form?. Maka persentase jawaban dari responden adalah 46,9\% menjawab "kuota internet terbatas", 44,9\% menjawab "gangguan sinyal", 2\% menjawab "tidak ada hp/gadget", $2 \%$ menjawab "layar hp terbatas", $2 \%$ menjawab "sinyal, kuota terbatas, hp tidak memadai", dan 4\% menjawab "tidak ada". Maka dapat kita ketahui bahwa, kendala yang paling banyak dialami adalah kendala dari kuota yang terbatas, kemudian gangguan sinyal yang mungkin sering dialami terutama di wilayah pedalaman, serta beberapa kendala seperti fasilitas alat elektronik yang tidak memadai, dan lainnya.

Selain dari kuesioner yang ditujukan kepada siswa, penulis juga melakukan wawancara online kepada beberapa guru yang sudah pernah/sering menggunakan google form sebagai instrument dalam penilaian pembelajaran siswa. Pertanyaan yang diajukan peneliti dalam wawancara adalah, sebagai berikut: (1) bagaimana tanggapan ibu/bapak terhadap penggunaan google form dalam penilaian pembelajaran?, (2) keuntungan apa saja yang diproleh dalam penilaian pembelajaran menggunakan google form?, (3) apakah ada hambatan yang dialami?, (4) apakah google form dianggap efektif dalam penilaian pembelajaran siswa?.

Sumber wawancara pertama, oleh Maya Marliana, S.Pd. sebagai guru di MI Miftahul Falah Bandung. Maya mengatakan bahwa: (1) penggunaan google form dalam penilaian pembelajaran sangat membantu terutama untuk PTS, UAS, dan ulangan harian;, (2) dengan menggunakan google form, guru tidak perlu lagi menghitung nilai secara manual, karena sudah disetting di dalam google form,; (3) hambatan yang dialami hanya karena factor jaringan internet/sinyal,; (4) penggunaan google form dalam penilaian pembelajaran dianggap sangat efektif dalam melakukan penilaian/ulangan, adapun jika digunakan untuk tugas harian masih dirasa kurang efektif karena kendala sinyal dan transparansi data yang sangat jelas. 
Sumber kedua, oleh Saiful Hidayat, S.Pd. sebagai guru di MI Al-Musthofa Bandung. Saiful mengatakan bahwa: (1) tanggapan saya terhadap google form di lembaga kami khususnya kelas 4, cukup efektif penggunaanya; (2) hasilnya langsung ada tanpa harus diperiksa secara manual, sudah ada diagram, serta analisis pada setiap butir soalnya, (3) pada awal penggunaan google form dilembaga kami, kurang efektif karena masih banyak orang tua siswa yang belum mengerti akan teknologi, waktunya kurang efektif sehingga tidak tepat waktu dalam mengisi, pembuatan google form cukup lama, belum lagi harus menyiapkan materi berbasis video dsb,; (4) penggunaan google form cukup efektif dalam melakukan evaluasi/penilaian pembelajaran.

Sumber ketiga, oleh Mudniah Sholihah, S.Pd. sebagai guru di Yayasan Rumah Ilmu arRaudhloh Bandung. Mudniah mengatakan bahwa: (1) google form dalam sebagai instrument penilaian sudah vukup baik digunakan, (2) keuntungan yang didapat ketika menggunakan google form yaitu mempercepat dan mempermudah dalam memperoleh hasil, ramah lingkungan dan hemat biaya karena tidak perlu menggunakan kertas/biaya printing. (3) hambatan dalam penggunaan google form tenatu ada, contohnya seperti kendala ketika jaringan/sinyal kurang baik, email guru juga harus selalu aktif dengan sandinya/tidak bias lupa sandi email karena tidak akan bias mengakses google. (4) selama pembelajaran daring berlangsung, penggunaan google form dalam proses penilaian cukup efektif dan sangat membantu guru, namun sepertinya ketika pembelajaran sudah berlangsung tatap muka, penggunaan google form hanya akan dijadikan opsi kedua karena tidak setiap siswa atau wali bias stay dengan hp atau jaringan yang memadai.

Dari hasil wawancara yang dilakukan, dapat disimpulkaan bahwa penilaian pembelajaran menggunakan google dianggap efektif. Penyajikan data dan diagram secara otomatis, membuat guru tidak perlu menghitung hasil penilaian secara manual, sehingga dapat mempermudah guru dalam penilaian khususnya ketika PTS, UTS, atau lainnya. Adapun hambatan yang dialami diantaranya karena adanya ganguan jaringan/sinyal, serta pengetahuan orang tua terhadap teknologi yang masih minim, sehingga di awal akan terjadi hambatan akibat keterlambatan dalam proses penilaian. Namun seiring berjalannya waktu, penggunaan penilaian perbasis web sudah jauh lebih dikenal orang masyarakat khususnya orang tua sisa, sehinggadapat dengan mudah diterapkan.

Dari hasil kuesioner dan wawancara yang sudah dilakukan, maka peneliti memperoleh kesimpulan sebagai berikut: (1) penggunakan google form dalam proses penilaian pembelajaran dianggap cukup efektif oleh guru karena mempermudah guru dalam mengolah data hasil penilaian secara otomatis, sehingga guru tidak perlu mengolah data secara manual sehingga dapat mengefisiensikan waktu. Siswa juga mudah mengakses soal dan bias cepat dalam memberikan timbal balik, meningkatkan kemandirian siswa, mempernudah siswa dalam pengayaan, dan interaksi siswa dengan guru.; (2) hambatan yang dialami guru dan siswa sebagian besar diakibatkan dari adanya gangguan jaringan/sinyal, dan beberapa gangguan lain seperti fasilitas yang belum memadai, ada beberapa siswa/wali yang belum memahami penggunaan teknologi.

\section{KESIMPULAN}

Pada penelitian ini, peneliti memperoleh kesimpulan sebagai berikut: (1) penggunakan google form dalam proses penilaian pembelajaran dianggap cukup efektif oleh guru karena mempermudah guru dalam mengolah data hasil penilaian secara otomatis, sehingga guru tidak perlu mengolah data secara manual sehingga dapat mengefisiensikan waktu. Siswa juga mudah mengakses soal dan bias cepat dalam memberikan timbal balik, meningkatkan kemandirian siswa, mempernudah siswa dalam pengayaan, dan interaksi siswa dengan guru.; (2) hambatan yang dialami guru dan siswa sebagian besar diakibatkan dari adanya gangguan jaringan/sinyal, dan beberapa gangguan lain seperti fasilitas yang belum memadai.

\section{SARAN}

Penelitian selanjutnya bisa dikembangkan ke dalam cangkupan yang lebih luas, agar hasil yang diperoleh lebih akurat. Penelitian juga berfokus pada pemberian solusi suatu permasalahan atau hambatan yang telah ketahui. 


\section{UCAPAN TERIMA KASIH}

Peneliti mengucapkan terima kasih kepada para narasumber, dosen pembimbing dan partisipan yang telah membantu terselenggaranya penelitian ini.

\section{DAFTAR PUSTAKA}

Batubara, D. S. (2017). Kompetensi Teknologi Informasi dan Komunikasi Guru SD/MI. MUALLIMUNA: Jurnal Madrasah Ibtidaiyah, 3(1), 48-65. Retrieved from http://ojs.uniska-bjm.ac.id/index.php/muallimuna ISSN:

Batubara, H. H. (2016). Di Prodi Pgmi Uniska Muhammad Arsyad Al Banjari. Universitas Islam Kalimantan MAB, 8(1), 40-50.

Fajriah, Z. (2015). PENINGKATAN PENGUASAAN KOSAKATA BAHASA ARAB ( MUFRADAT ) MELALUI PENGGUNAAN MEDIA KARTU KATA BERGAMBAR ( Penelitian Tindakan Pada Siswa kelas I MI Nurul HakimKediri Lombok Barat Tahun 2015 ). AT) MELALUI PENGGUNAAN MEDIA KARTU KATA BERGAMBAR (Penelitian Tindakan Pada Siswa Kelas I MI Nurul HakimKediri Lombok Barat Tahun 2015) Zhratun, (Hamdani:, 107-126. https://doi.org/10.1109/MRA.2014.2360283

Farida, I. (2017). Evaluasi Pembelajaran Berdasarkan Kurikulum Nasional. Rosdakarya.

Imania, K. A., \& Bariah, S. K. (2019). Rancangan Pengembangan Instrumen Penilaian Pembelajaran Berbasis Daring. Jurnal Petik, 5(1), 31-47. https://doi.org/10.31980/jpetik.v5i1.445

Jamaluddin, D., Ratnasih, T., Gunawan, H., \& Paujiah, E. (2020). Pembelajaran Daring Masa Pandemik Covid-19 Pada Calon Guru : Hambatan, Solusi dan Proyeksi. Karya Tulis Ilmiah UIN Sunan Gunung Djjati Bandung, 1-10. Retrieved from http://digilib.uinsgd.ac.id/30518/

Kartono. (2020). Jurnal Visipena. Jurnal Visipena, 11(1), 99-115.

Lestari, W. I., \& Putra, E. D. (2020). Efektivitas Pembelajaran Matematika Menggunakan Media Pemberian Tugas Google Form Di Masa Pandemi Covid-19 Terhadap Hasil Belajar Siswa. Laplace: Jurnal Pendidikan Matematika, 3(2), 129-141. https://doi.org/10.31537/laplace.v3i2.379

Rahmanto, M. A., \& Bunyamin. (2020). Efektivitas Media Pembelajaran Daring Melalui Google Classroom. Jurnal Pendidikan Islam, 11(November), 119-135.

Rusman. (2018). Belajar dan Pembelajaran Berbasis Komputer. Bandung: Alfabeta.

Sugiyono. (2018). Metode Penelitian Pendidikan Pendekatan Kuantitatif, Kualitatif,dan R\&D. Bandung: Alfabeta.

Suryanovika, C. (2020). Google Forms: An Assessment Tool Accommodating the Generation-Z Students' Learning Needs. E-Structural, 2(2), 140-152. https://doi.org/10.33633/es.v2i2.3257

Thohir, M., \& Muslimah, K. C. (2020). Evaluation of Arabic Learning Outcomes Using Google Form During School Quarantine Due to Covid-19 Pandemic. Studia Religia Jurnal Pemikiran Dan Pendidikan Islam, 4(1), 12-22. Retrieved from index.php/Studia/article/view/5051/pdf

Wijayanti, R., \& Hermanto, D. (2021). Efektivitas Penggunaan Aplikasi Quizizz Pada Matakuliah Matematika Sekolah Ditinjau dari Motivasi dan Hasil Belajar Mahasiswa, 05(01), 347-356. 